MABR

7,1

70

Received 29 March 2021

Revised 12 September 2021 13 October 2021

30 November 2021

7 December 2021

13 December 2021

Accepted 20 December 2021

\section{Assessment of port governance model: evidence from the Brazilian ports}

\author{
Cláudio de Jesus Marques Soares \\ Rio Port Authority's Board of Councillors - CDRJ, \\ Rio de Janeiro, Brazil and \\ Transport Engineering Department, UFRJ, Rio de Janeiro, Brazil, and \\ Ana Cristina Paixão Casaca \\ World Shipping Portugal, Parede, Portugal and \\ CIMOSM Centro de Investigação em Modelação e Optimização de Sistemas \\ Multifuncionais (Multifunctional Systems Modelling and Optimization Research Centre), \\ Instituto Politecnico de Lisboa Instituto Superior de Engenharia de Lisboa, \\ Lisbon, Portugal
}

\begin{abstract}
Purpose - Since enacting Act 8630/93, Brazilian port activities have been going through significant modifications, changing from the public port service management to the landlord model. Act 12815/2013 enforced a new regulatory framework increasing Port Authorities' dependence on the Federal Government. Since 2019, the Government has attempted to elaborate a Port Authorities' identity based on the private port governance model inspired by the Australian and United Kingdom ones. This paper assesses Brazilian's Port Authorities management models from 1993 to 2020 and considers the Australian, the United Kingdom and Antwerp port governance models as benchmarks.

Design/methodology/approach - This paper adopts a two-step methodological approach, namely a combined desk and field research methodological approach and considers three essential resources: government legislative acts and published data available online; ports' data and information issued by governments' agencies, academic papers and national and international ports' websites; and a semi-structured questionnaire survey targeting the leading associations representing port users, foreign trade and stevedoring companies.

Findings - The outcome shows that the solutions to overcome the existing Brazilian Port Authority governance problems remain in the Federal Government's hands by (1) removing its control through bureaucracy, (2) preventing the party-political influence following in the public ports and (3) decentralising port management by chief executive officers named by Port Authority Councils.

Research limitations/implications - This paper does not explore the regulatory frameworks underlying the "Lease Terminal" and "Private User Terminal".

Originality/value - This paper assesses the management models that led Brazilian's Port Authorities from 1993 to 2020, comparing them with the UK and Australian private service port and Antwerp landlord model.
\end{abstract}

Keywords Port management models, Port authority, Brazil

Paper type Research paper

\section{Introduction}

In Brazil, on February 23, 1993, Act 8630, the so-called 1993 Ports Act, entered into force and the Federal Government (FedGov) incorporated the landlord port authority governance model. This model allows port authorities to operate as economic catalysts by promoting investment, tax revenue, employment, trade volume and increasing regional and national gross domestic product (Notteboom et al., 2021). They can act as development agencies by planning and promoting industrial activities and logistical operations linked to their

(C) Pacific Star Group Education Foundation. Licensed re-use rights only. 
industrial and port complex infrastructures on a regional basis, following national planning. Unfortunately, the Brazilian authorities failed to implement the complementary structuring actions foreseen in 1993 to consolidate the landlord governance model. Technicians argue that the FedGov should have had implemented at least three structuring measures: (1) the Dock Companies (DCs) (i.e. Port Authorities) replacement which are federal companies run by the Federal Government, ruled by the Corporation Act, by state public companies or state authority; (2) the renewal of the DCs personnel; and (3) the Pension Fund Institute support to foster public workers' retirement.

Likewise, the FedGov failed to address these measures. Apart from transferring the port operation to private companies, the 1993 Port Act creates the Port Authority Council (PAC), a deliberative and autonomous council formed by public authorities, stevedoring companies, dockworkers and port users. The Federal Government's landlord model lack of consolidation drove, to another port regulatory intervention (Act 12815/2013), forcing port authorities into a central government's mainstream centralised management. According to the National Audit Office Report (NAOR), port authorities management centralisation was motivated by three government perception pillars (Court of Auditors of the Union (CAU), 2020): (1) the need for an integrated public port policy; (2) the government team's needs to understand the ports economicregulatory framework; and (3) the need to reduce the political party control on the public ports.

Overall, Act 12815/2013 aimed to allow private terminals (i.e. Terminals of Private Use, TPU) to handle third-party cargo without restriction. Under Act 8630/1993 and Decree 6620/2008, more than 50\% of the TPU handled cargo had to belong to the terminal owner. Act 12815/2013 overpassed that condition; however, it undermined the landlord governance model in the following aspects (CAU, 2020): (1) the change of the PACs' role from a deliberative to consultative one; (2) the partisan political bases regarding the chief executive officers (CEOs) appointment resulting in strong party-political influence in port management; (3) the investment decisions start being approved and conducted by the Federal Government; and (4) bureaucracy driven by accountability overload that undermines Port Authority governance.

Subject to this background, assesses Brazilian's Port Authorities management models from 1993 to 2020 and their implications leading the FedGov to consider the private service port. It considers the Australian, United Kingdom (UK) and Antwerp port governance models as benchmarks to identify their implications on the Brazilian port model. The paper is structured into seven sections. The current section puts the paper into context and identifies its structure. Section 2 presents the literature review. Research methodology is presented in Section 3; the paper adopts a combined desk and field research methodological approach. Section 4 investigates the Brazilian seaports and explains the main facts that have shaped Brazilian port governance models. Section 5 analyses port governance models in Australia, the UK and Belgium (Antwerp). Section 6 presents the survey analysis and exposes main stakeholders' perception concerning Port Authorities activities regarding the Federal Government project to fully privatise the existing landlord model. Finally, Section 7 concludes.

\section{Literature review}

At the beginning of this century, the main factors driving port industry changes were shipping technology, cargo-handling system, storage equipment and management, which should be added information and communication technology, port operations and institutional environment (Notteboom and Winkelmans, 2001). Such a changeable atmosphere affects seaports' governance and management (Tovar and Wall, 2014; Zheng and Negenborn, 2014). In addition, larger vessels' demand increasing seaport capacity to handle their cargo and respond to the increasing demands on their logistics systems. Under uncertain scenarios regarding global trade patterns, seaports must react to meet this uncertainty; therefore, they should apply agility to their operations (Paixão and Marlow, 2003).

Assessment of port

governance model 
MABR

7,1

\section{2}

In maritime transport, agility is associated to the concept of efficiency toward high cargohandling capacity with lower costs per unit handled (Lunkes et al., 2013).

The World Bank Toolkit identified five port governance models (see Table 1) based on the public and private sectors' level of control and responsibility (World Bank, 2007). The landlord port governance model could be seen as stuck in the middle of the scale and characterised by a mixed public-private business model. It must have a long-time planning outlook and act as a regulatory body, following the countries' transport/infrastructure ministry rules. Hence, it has been the most successful port governance model worldwide. According to the European Port Governance Report (European Sea Ports Organisation, 2010), the landlord function can be considered the main port governance model.

Besides, port authorities are responsible for their seaports competitive, sustainable and safe development (Notteboom and Winkelmans, 2001). The literature explains that port authorities' strategic decisions are subject to executives' specific beliefs who change their perception across the industry over time, and based on self-cognition, strategic decisions are primarily determined by executives' past experiences. Executives outside the port industry without conceptual knowledge about the sector face difficulty in making decisions and taking the appropriate path. Unlike the shipping industry, port authorities work in a double derived demand uncertain environment (Paixão and Marlow, 2003) where many players interact, which explains why their strategic decisions must include political, economic, environmental and commercial interests. In a globalised business model, customers require close collaboration among business partners and port authorities to streamline their supply chains; therefore, port authorities must "calibrate" the public-private demands adjusting its strategy (Van der Lugt et al., 2017).

Brazilian port governance some studies can be found in the body of the literature. Barros and Barros (2013) affirmed that the low modal integration and port infrastructure deficit hinders the advanced stage of the Brazilian ports. Galvão et al. $(2013,2017)$ stated that in Brazil, the 1993 Ports Act had its effects and policy changes regarding the Government's strategic sectors during the 1990 s and early 2000 s. This paper contributes to the body of the literature because it builds on the work done so far.

\section{Methodology}

This paper adopts a two-step methodological approach, namely a combined desk and field research methodological approach. The first step uses a desk research methodological approach, namely an external desk research approach. An external desk research approach means that information is gathered outside the organisation's boundaries. This information can be published in soft or hard copies and gathered online or physically in different governmental agencies, respectively. However, it does not guarantee that all the necessary information is available.

The present research gathers information about port governance models in Brazil, Australia, the UK and Antwerp (Belgium). Information about Australian, British and

Table 1.

Port governance models

\begin{tabular}{lllll}
\hline Type & Infrastructure & Superstructure & Port labour & Other functions \\
\hline Public service Port & Public & Public & Public & Majority private \\
Tool port & Public & Public & Public/Private & Public/private \\
Landlord Port & Public & Private & Private & Public/private \\
Corporatised Ports & Public & Private & Private & Majority private \\
Private service Ports & Private & Private & Private & Majority private
\end{tabular}

Note(s): Drawn by authors based on Port Management Models

Source(s): World Bank (2007) 
Belgium port governance models is necessary since it will be used as a benchmark. Information is gathered from three sources. The first is the FedGov legislative acts and published data available online. These data concern port legislation and its regulatory framework to assess the market beyond the public and private agents' publication. The second one concerns ports' data and information issued by government agencies, academic papers and the national and international ports websites. Finally, the third one consists of a semi-structured questionnaire survey targeting the leading associations representing Brazilian port stakeholders. Section 4 presents the external desk research approach for Brazil, and Section 5 for Australia, the UK and Antwerp (Belgium).

The second step concerns a field research approach using a semi-structured survey questionnaire addressing two important issues. First, it addressed port authority governance under three scenarios drawn from the body of the literature (Tongzon, 1995; Peters, 2001; Notteboom and Winkelmans, 2001). The first one, under public and centralised port management, with managers named by the Federal Government, represents the current situation in Brazil. Under private and decentralised port management led by private corporations, the second scenario is seen in some Australian Port Authorities and UK Ports. Finally, under public and decentralised port management conducted by managers named by the $\mathrm{PAC}$, the third scenario is placed in the Port of Antwerp and its principles led to the enactment of Act 8630/1993. Second based on the existing literature (Tongzon, 1995; Peters, 2001; Notteboom and Winkelmans, 2001), it incorporated bringing some critical key port governance competitiveness determinants (Tongzon, 1995; Peters, 2001; Notteboom and Winkelmans, 2001). They are: (1) operational efficiency of ports/terminals; (2) port infrastructure charges; (3) cargo-handling tariffs; (4) reliability in the port authority; (5) selection of port preference by shippers and carriers; (6) level of dredging of access channels and evolution basins; (7) contractual flexibility to adapt to changes in the market; (8) land accessibility; and (9) diversity of supply of services and products. A five-point Likert scale was used $(1=$ terrible; $2=$ bad; $3=$ reasonable; $4=$ good and $5=$ great) to classify these key determinants, according with the governance scenario perception.

This survey was sent to three leading port authorities' stakeholders associations, which represent the stevedoring companies, trade companies and shippers. The Brazilian Ports Terminals Association is a non-profit organisation representing over 100 stevedoring companies operating in leasing areas into Port Authorities, answering for more than $70 \%$ of the cargo handling in the Brazilian maritime trade. The Brazilian Foreign Trade Association is a non-profit organisation representing the Brazilian trade companies, automobile industries, stevedoring companies, shipowners association, machines industries and consulting companies. Finally, the Brazilian Shippers Association is a non-profit organisation representing the interests of port users as shippers, exporters, importers, general cargo port terminals, shipowners, brokers, carriers and freight forwarders.

This work discarded the possibility of conducting interviews with the leading Brazilian Port Authorities chief executive officers (CEOs) because these positions are FedGov oriented, i.e., theBrazilian Government nominates the people who take responsibility for these positions. This is a political philosophy used by Portuguese-speaking countries, not only Brazil. Consequently, as these CEOs follow the Government's guidelines, this research could run the risk of being biased, thus undermining the impartiality of the research. Finally, the survey questionnaire was sent to these representative associations via e-mail in August 2021. Their answers were also received in the same month.

\section{The Brazilian Port Authorities drama}

Brazil counts 37 public ports, where the FedGov manages 19, and 18 are delegated ports to states or municipalities. In addition, it has 144 private terminals (TPUs) located outside the

Assessment of port

governance model 
MABR

7,1

74

jurisdictional borders of the organised seaports' areas which handle $70 \%$ of the country's bulk cargo (National Waterway Transportation Agency NWTA, 2021). In contrast, the leased terminals deal with $30 \%$ of the cargo handled under the Port Authority jurisdiction. Furthermore, bulk cargo terminals throughputs are far less affected by human intervention or operational planning since their operations are standardised and driven by automation systems. Regardless of their location or management standards, their business model remains the same. Containers terminals leased under the Port Authorities jurisdiction handle $70 \%$ of the country's containerised cargo, whereas the TPUs deal with $30 \%$. Moreover, container terminals' throughputs are far more affected by human intervention, with their operational planning driving their operational cost rather than bulk terminals. Hence, where container terminals are settled matters for their business model. For example, container terminals outside the Port Authority jurisdiction do not deal with dockers unions or pay leasing according to their operational performance or even down payment for bid. On the other hand, they must construct their infrastructure and superstructure and manage their maintenance.

Figures 1 and 2 show Brazilian's landlord port governance model operational response. Figure 1 shows leasing terminals and TPUs container handling throughput, combined. Figure 2 exposes that TPUs doubled their TEU handling market share in the last decade, soaring from $15 \%$ to $30 \%$ of the market share for box handling. Their main gain occurred between 2010 and 2015 when TPUs market share grew $73 \%$, contrasting with the $19 \%$ growth between 2015 and 2020, resulting in a smooth growth trend.

Between the enactment of Act 8630/1993 and the end of 2002, the FedGov granted more than 140 lease contracts (CAU, 2020). Similarly, the figures are still not cooperating after seven years of Act 12815/2013, with the Federal Government's dismantling an entire regulatory framework that was still in progress to its full implementation, arguing adjustments needs to increase investments in the sector. Figure 3 shows TPUs' cargo-handling gain just after enacting Act $12815 / 2013$. However, this comparison does not infer cargo loss by the leased terminals since the 20-foot equivalent (TUE) shipments have been steady during most of the decade; a slight advantage occurred for the TPUs between 2016 and 2017. Only when the 2015/2016 crisis derived from the country's economic and political turmoil resulting in the president's impeachment was overcome, did the container volume handled by private and leasing terminals normalise. The overall scenario infers that the TPUs increased their cargo shipment market share (ton/TEU) due to regulatory advantage rather than operational and/or cost performance.

Furthermore, although the Brazilian port throughput soared after 1993, the FedGov could not overcome the substantial party-political influence on Port Authorities' control, even after the new Act 12815/2013. Besides, the Government's excessive power and several

Figure 1.

Terminals container handling throughputs overview

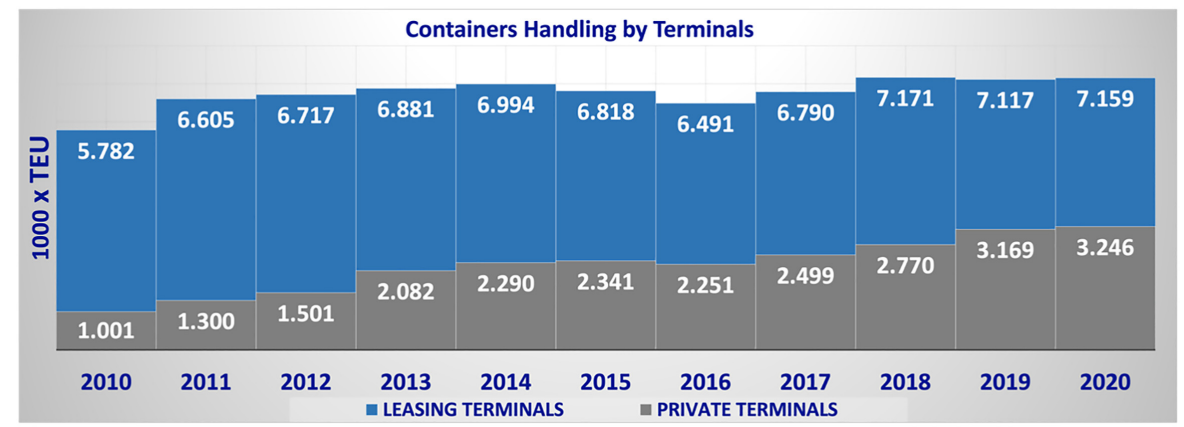

Source(s): Drawn by authors based on NWTA database (2020) 


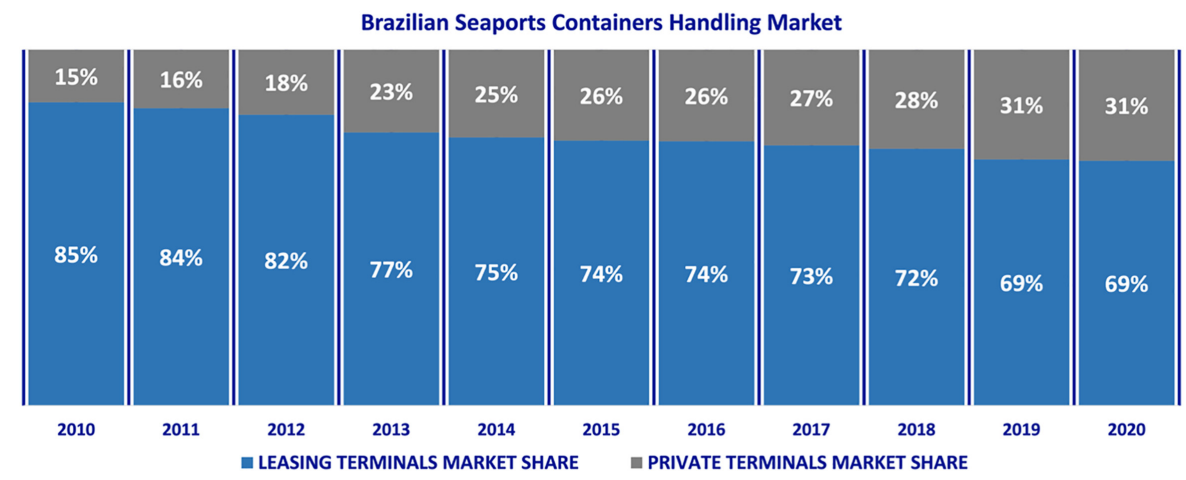

Source(s): Drawn by authors based on NWTA database (2020)

Assessment of port governance model

\section{5}

Figure 2.

Brazilian container handling terminal market by TEU

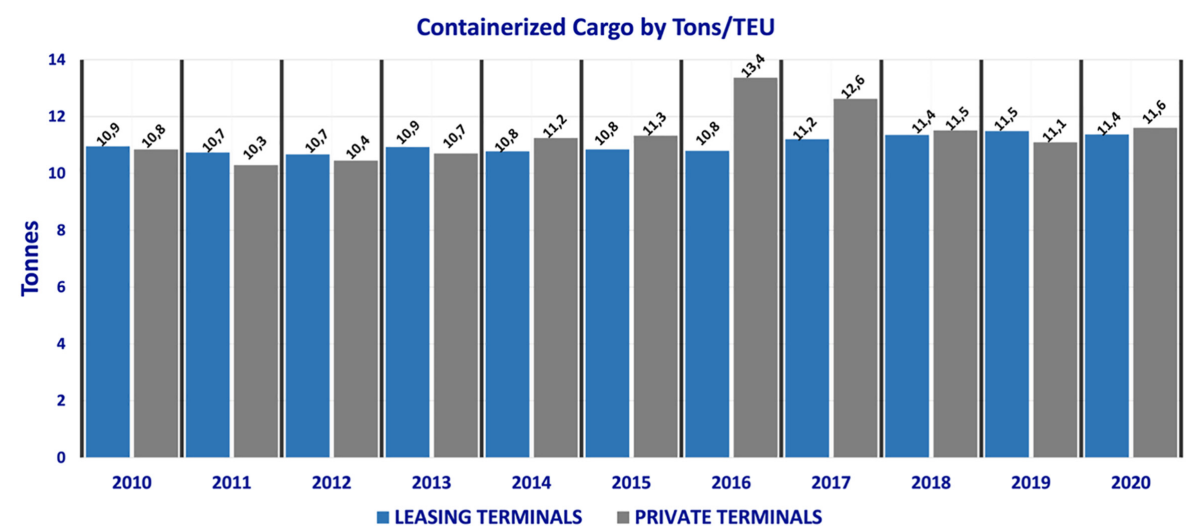

Source(s): Drawn by authors based on NWTA database - 2020
Figure 3.

Container handled (ton/

TEU) by leasing terminal vs private terminals

bureaucratic layers derived from that legislation slowed the ports' lease process. According to the NAOR (CAU, 2020), port leases have taken around 28 months in public ports.

Data released in late 2019 by the NWTA reveal that less than 12 of the 168 TPUs currently authorised have applied for an International Traffic Permit. Most of those TPUs got their authorisation to support offshore operations and/or operate as sea terminals in coastal shipping, mainly for handling their cargo, generally raw material, in the process of industrial verticalisation. In addition, less than $8 \%$ of authorised port facilities have the features of a multi-purpose, small-size terminal, in comparison to the large, specialised terminals under lease in the jurisdiction of the Port Authorities.

Since 2019, the Ministry of Infrastructure (MinInf) has been trying to give Port Authorities more administrative independence through several ordinances to accelerate the assessments of investments in public port infrastructure. By focusing on adding value in the port assets towards the privatisation process, the Government has been working hard to cut edges in Port Authorities' FedGov dependence, at least concerning the port projects issues.

Under a pandemic atmosphere (COVID-19), on 8 August 2020, the FedGov enacted Act $14047 / 2020$ containing various decentralised measures regarding the commercial and 
MABR

7,1

76

management relation among organised ports, their concessionaires and third parties. Like a legal umbrella, Act 14047/2020 covers several legal aspects targeting the operational leased contracts, including those for port facilities. The FedGov removed some mandatory provisions in the classic leased contracts such as the required methods and practices of carrying out the port terminal activities, the return of the assets at the end of the contract, adoption and compliance with customs supervision measures for goods, vehicles and persons. Leased contracts will be considered under the private companies' Act commercial rules although this will not exclude supervision by NWTA. Apart from the FedGov control, the MinInf seems to induct a commercially positive context towards Port Authorities' privatisation.

\section{Port management experiences in Australia, United Kingdom and Belgium}

5.1 The Australian private service port experience

Australia has over 70 ports spread all over its territory with a mixed model granting part of its port activities to private groups consortia or business associations that account with three main regulatory frameworks:

(1) The State-Owned Corporations Act 1989 covering the landlord port governance model.

(2) The Ports and Maritime Administration Act 1995 covering the private service port model and working as implement legislation for the Port Management (Local Ports) Regulations 2015 for the New South Wales (NSW), Northern (NT), Queensland (QLD) and Victorian (VIC) Territories; and

(3) The Port Authorities Act 1999 covering the private service port model in the Western Australia (WA) region.

Under those central legislations, Australia has five Port Authorities controlled by private groups. They work as full private service ports starting with Port of Brisbane that was privatised in 2010, in the QLD Territory, followed by the Ports of Botany, Kembla (2013) and New Castle (2014) in the NSW Territory; then Darwin (2015) in the NT Territory; and Melbourne (2016) in the VIC Territory. However, unlike the classic Port Authority landlord governance model, in the Australian private service port model, the maintenance of waterway access to the ports is not in charge of the government authorities. Local port authorities must contract dredging and beaconing services under the Central Government's approval and align with the national dredging plan.

When the private service port model started in 2010, it asked for pricing regime and port services regulation and the Australian Government enacted several ports management acts in 2015. Their objective was to grant the private service ports a regulatory framework to guarantee a safe, efficient and effective management under the Ports and Maritime Administration Act 1995. Thus, in 2015, that body of legislation established the operational rules and pricing regime for some ports designated by the Australian Government. To comply with the 2015 Ports Management Acts, the Government named an independent statutory body under the Utilities Commission Act 2000, which would be responsible for observing ports' access and the prices of services prescribed and provided by their private port authorities. The Australian Government's experience showed that it would be necessary to enact a new act, the Port Law Amendment Act 2020, to assess the pricing regime's effectiveness established by the 2015 Ports Management Acts.

Although the Australian port privatisation has short-term positive impacts on the States Governments' balance sheets, it may result in a risky port assets' underevaluation, increased port charges, impeded port competition, less port investment and less concern for the public 
interest in the long term (Chen et al., 2017). The Australian model has demonstrated so far the brutal demand for short-term financial returns that port operators must submit to these private consortia, seeking to meet their shareholders' goals.

The Australian Competition and Consumer Commission (ACCC) has appealed to the Federal Court on several occasions against NSW Ports, arguing "anti-competitive" and "illegal" acts. According to ACCC Reports (2018-2020) and several Australian Federal Court proceedings, the aim is to remove cartels' barriers to competition in supply and port services with implications for the cost of goods across the Australian economy that consumers ultimately support. However, there is no success due to the model contracts signed in the privatisation processes and the limited power of Australian Government interference in the private sector. The Port of Melbourne has experienced hefty infrastructure surcharges following the increase in the price of several services since the Victorian Government leased the Port of Melbourne in 2016 (ACCC, 2020). Port of Melbourne's users face a continuing increase in fees charged by stevedoring companies, making them urge a greater regulation to avoid damage to the Victorian economy (Victorian Transport Association, 2020). Higher rent, energy and other costs are the main arguments to justify the serial infrastructure surcharge at Melbourne's Port and further private port services in Australia.

\subsection{The UK privatisation port experience}

There are about 120 commercial ports in the UK (Maritime, 2021). These include major allpurpose ports, such as London and Liverpool; ferry ports, such as Dover; specialised container ports, such as Felixstowe; and ports catering for bulk traffic, such as coal or oil. Many smaller ports cater to local traffic or specialise in fishing or leisure boating (Maritime, 2021). However, most UK cargo traffic runs in a relatively small percentage of the commercial ports, where the top 20 ports account for $88 \%$ of the total cargo handled. The UK terminal representative organisations are similar to the Brazilian TPUs' representative organisations. In Brazil, only the Association of Private Port Terminals, representing the interests of 29 large fully private port terminals, brings together 56 TPUs. In the UK, two associations represent the country's port state's interests: The British Ports Association, holding around 107 ports and The UK Major Ports Group Ltd (UKMPG), holding around 42 ports operated by nine UKMPG members.

In the late 1980s and early 1990s, the UK privatised their largest ports, while minor ports remained in the hands of independent public trusts or municipal authorities. This privatisation abolished the National Dock Labour Scheme (NDLS), ended frequent port disruption periods that threatened the country's maritime trade and removed restrictive and archaic employment regulations required. Hence, there are three main models of ports' management in the UK, namely "Private Ownership", "Trust" and "Local Authority Owned Ports". Private Ownership ports are owned, run and invested by international groups or private companies commercially.

The so-called British port privatisation was all about "ports on sale", which meant selling state-owned ports assets and railway ports in the early 1980s rather than planning a new governance approach to improve port management, infrastructure and facilities. It aimed to remove public ownership and its accountability from government rule, including its regulatory command. Conceptually speaking, there is no classic landlord port governance model in the UK as in continental Europe. Hence, the UK port reform model was a unique port privatisation program worldwide. Hence, taking advantage of the lack of port policy to redirect the outcome, the financial markets drove the British port industry into heavy consolidation, imposing monopolistic practices (Brooks and Pallis, 2012). The Department for Transport shows that the UK port tonnage is mainly driven by movements occurring in the English ports, which made up $70 \%$ of cargo handled in 2019. When the remaining major UK
Assessment of port

governance model 
MABR

7,1

78

ports are considered, their market share soared to $98 \%$ of the total cargo handled in the UK. However, some pitfalls are worth mentioning.

The World Bank (2007) claimed that one of the UK's port system main structural problems, mainly among Trust Ports, was their boards' composition. It tended to be strongly made up of port users' representatives who were by nature reluctant to authorise tariff increases sufficient to generate the revenues needed to allow for depreciation and subsequent reinvestment in port facilities. In addition, there was general concern that Britain could not have enough port capacity as private investment delayed well behind trade growth (Baird and Valentine, 2006). A focus on short-term returns weakens corporations' long-term perspective, reducing their ability to grow by reducing the accumulated profits that could be used as investments to generate long-term value. In this scenario, it would not be difficult to understand China's shareholder control policy by the Chinese State of all its global corporations.

Baird and Valentine (2006) identified that port privatisation was used to undo many Second World War nationalisations. The UK's reform was as much about reversing this hallmark seen as a socialist philosophy as it was about selling companies that should not belong, under capitalist philosophy, in public hands (Baird and Valentine, 2006). They were defective from the public/taxpayer interest view and, for a long time, there was less investment than could have occurred (Saundry and Turnbull, 1997; Baird, 2000). As expected, the investments only came along to respond to maritime trade growth, so private investors began to acquire port infrastructure holdings. There has been considerable investment in new UK port facilities in recent years, with the port owners running after to cope with demand.

\subsection{The Port of Antwerp current governance overview}

The Port of Antwerp (PoA) was the FedGov's inspiration almost 30 years ago towards establishing its landlord port governance model. Port of Antwerp was initially a city port, but it moved its operations away from city centres across the time. Since Second World War, the PoA has been acting under the landlord port governance model principles delineated by a combined public and private orientation. However, its strategy began taking a new design in 1997, when, at the request of the local port community players, such as port operators, industrial companies, logistics companies, the Belgium Government recognised that the Port needed to adopt more economic principles. To deepen its long-term planning and face the new global challenges, it would be necessary to change the Municipal Council model renewed every six years, since the investment policy depended upon the elections' result. Hence, Antwerp's Port became a self-governing municipal body with its own governance rules, run by port and maritime professionals, reporting to a Port Municipal Council comprising 18 councillors, 17 of whom were elected politicians, representing individually different port community economic and social areas and 1 representing the private initiative.

Later in 2016, the PoA refined the model and moved to a public company's limited liability status. Its board of directors comprises private sector and government authority representatives, ensuring democratic control of the Port supervised by independent auditors. The board of directors comprises six elected politicians representing the different port community economic and social sectors and six representatives of private initiatives chosen by private companies' CEOs outside the PoA to avoid any possible conflict of interest. The board of directors elect the PoA president (CEO). The new CEO accompanies the previous one for one year, who retains all his authority over the port until the elected president takes up the mandate definitively. The daily administration is carried out by an Executive Committee, whose members are also appointed by the board of directors and the CEO chairs this Executive Committee. Finally, the PoA continues to work with the Belgium Government and the port community to implement the Port's strategic planning to generate value for the region and the country. 
In 2019, Antwerp's cargo volume was more than 240 million tonnes, making the PoA by far the largest Belgium port and the second-largest European port, ranking 14th in the 20 largest container ports in the world. It handled more than 11 million TEU with more than 130 million cargo tons regarding container handling. Acting as a global player, the PoA created a subsidiary, the Port of Antwerp International, to invest in ports abroad and port-related projects in strategic regions, such as Brazil, seeking horizontal integration.
Assessment of port governance model

\section{Unbalance of the Brazilian port governance models}

During the second decade of the 21st century, there was an overwhelming feeling of constant hunger for "revolutions" rather than "evolution" in port authorities' governance. What is perceivable is something symptomatic, i.e., incomplete and misunderstandings actions in the port industry, creating exotic derivatives in the management, mainly in federal public ports, contrasting with global reference models. The Brazilian' port authorities have been experimenting with trial-and-error different governance efforts without removing the main factors that undermined the port authorities' management. Moreover, even though the terminals' throughput run by stevedoring companies stands in equal terms as the sector's international best practice, the Brazilian experience goes against the prevailing international practice (CAU, 2020). In most reference countries, stevedoring companies look for leasing areas into port authorities on the landlord model. On the contrary, in Brazil, most investors prefer to install themselves outside the organised ports (CAU, 2020).

The current FedGov plans to move into the private service port indicate a port reform supported by ideology rather than operational needs, as was the case of the port reform in the UK; the UK urged to abolish the NDLS scheme. In Brazil, the FedGov excessive control resulted in strong party-political influence in port management, and bureaucracy overload undermined the role to be played by port authorities. However, according to the Brazilian MinInf (Portogente, 2020), the main objective of the Brazilian port reform program toward the private service port is to develop the appropriate port complex, based on efficiency and timely investment, and strengthen port integration in their communities and cities. Hereafter, a question arises: What is the perception that the directly impacted port community has about the issue? The answer to this question is given in Figures 4-6 and Table 2, which are the survey outcome.

Figure 4 shows port users' competitiveness perception regarding port authority performance by governance model. According to them, the operational efficiency, infrastructure charges, cargo-handling tariffs, reliability, port preference and level of dredging would be better reliable in the public and decentralised governance model. This outcome contrasts with the private and decentralised governance model that would be considered terrible regarding operational efficiency, infrastructure charges, cargo-handling tariffs, reliability and land accessibility. On the other hand, the private and decentralised governance model would be considered reasonable regarding port preference, level of dredging and diversity of services. According to the perception of the port users, the only key determinant that would be better in the private and decentralised governance model is the contractual flexibility. Regarding the current model (public and centralised port authority), the only competitiveness aspect that is considered excellent is the port preference, aligned with the public and decentralised governance model. The remaining determinant keys are classified as bad or terrible.

Figure 5 shows the stevedoring companies competitiveness perception regarding port authority performance by governance model. According to them, the operational efficiency, infrastructure charges, cargo-handling tariffs and reliability would be better in the public and decentralised governance model than in the private and decentralised governance model but respectively classified as reasonable and good for reliability and operational efficiency. The private and decentralised governance model would be considered inadequate for the stevedoring companies regarding infrastructure charges and cargo-handling tariffs. On the 


\section{MABR}

7,1

\section{0}

Figure 4.

Port users' competitiveness perception
Table 2.

Port authority competitiveness perception

\section{LOGÍSTICA BRASIL VIEW}

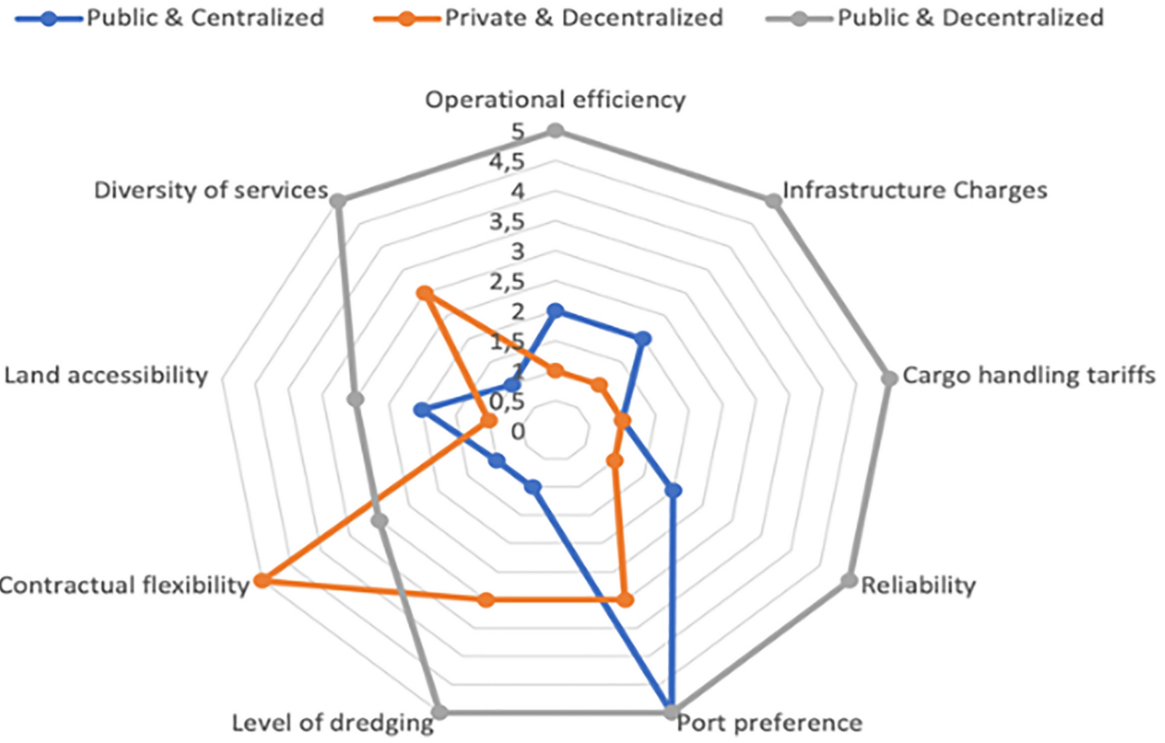

\begin{tabular}{|c|c|c|c|}
\hline \multicolumn{4}{|c|}{$\begin{array}{l}\text { AVERAGE PERCEPTION OF PORT AUTHORITY } \\
\text { PERFORMANCE BY GOVERNANCE MODEL }\end{array}$} \\
\hline $100 \%=$ Great & Pu \& Ce & $\operatorname{Pr} \& \mathrm{De}$ & Pu \& De \\
\hline 1 Operational efficiency & $47 \%$ & $67 \%$ 个 & $93 \% \uparrow$ \\
\hline 2 Infrastructure Charges & $47 \%$ & $47 \%-$ & $93 \% \uparrow$ \\
\hline 3 Cargo handling tariffs & $40 \%$ & $47 \% \uparrow$ & $93 \% \uparrow$ \\
\hline 4 Reliability & $53 \%$ & $47 \% \downarrow$ & $100 \% \uparrow$ \\
\hline 5 Port preference & $73 \%$ & $67 \% \downarrow$ & $93 \%$ \\
\hline 6 Level of dredging & $33 \%$ & $73 \% \uparrow$ & $87 \%$ \\
\hline 7 Contractual flexibility & $40 \%$ & $93 \% \uparrow$ & $80 \%$ \\
\hline 8 Land accessibility & $53 \%$ & $60 \% \uparrow$ & $73 \%$ \\
\hline 9 Diversity of services & $40 \%$ & $80 \% \uparrow$ & $93 \% \uparrow$ \\
\hline 10 The Overall Perception & $47 \%$ & $64 \% \uparrow$ & $90 \% \uparrow$ \\
\hline Comparative Perception & $\mathrm{Pu} \& \mathrm{Ce}$ & $17 \% \uparrow$ & $42 \% \uparrow$ \\
\hline $\begin{array}{l}\text { Pu } \& \text { Ce }=\text { Public } \& \text { Centraliz } \\
\operatorname{Pr} \& \text { De }=\text { Private } \& \text { Decentr } \\
\text { Pu \& De }=\text { Public } \& \text { Decentra }\end{array}$ & $\begin{array}{l}\text { ed } \\
\text { alized } \\
\text { alized }\end{array}$ & & \\
\hline
\end{tabular}

other hand, the private and decentralised governance model would be considered as good as the public and decentralised governance model regarding port preference, level of dredging and land accessibility. However, the private and decentralised governance model would be considered better than the public and decentralised governance model regarding contractual flexibility and diversity of services. Therefore, those two last ones have a great perception by the stevedoring companies. 


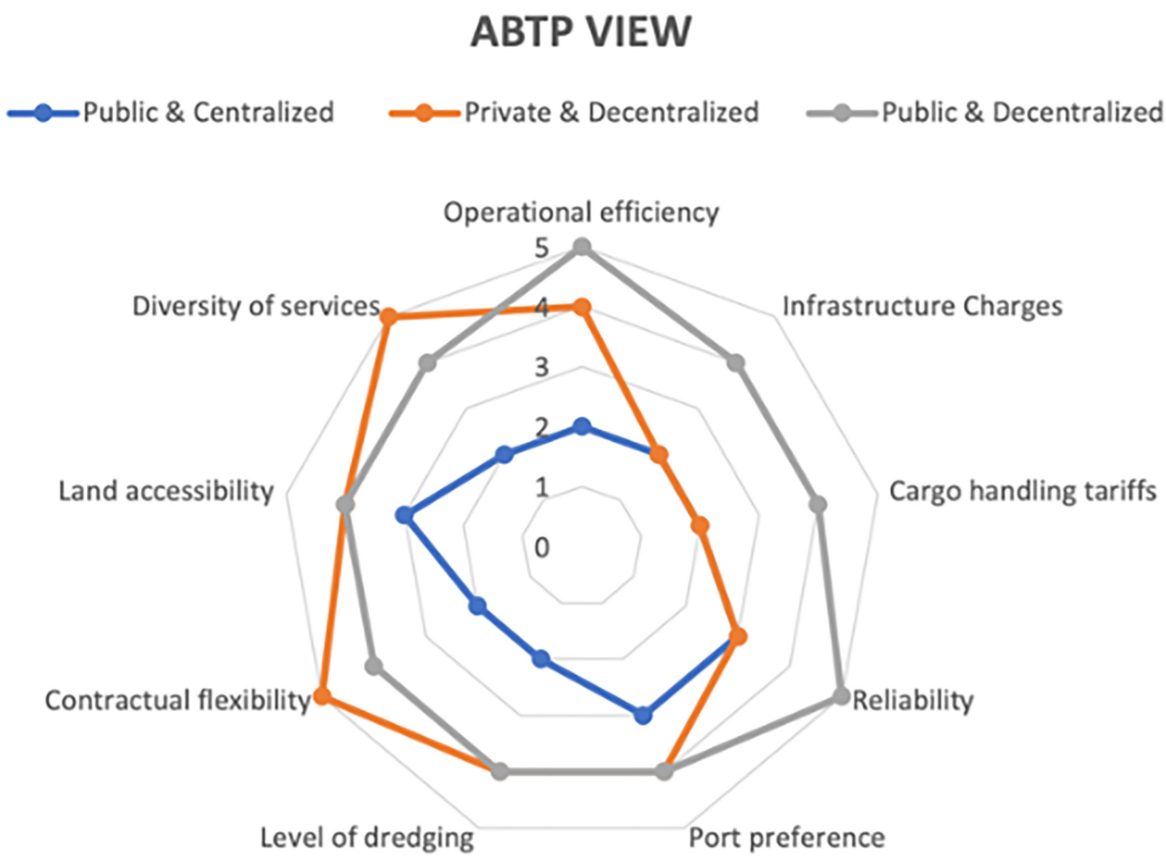

Assessment of port governance model

Figure 6 shows trade companies (importers and exporters) competitiveness perception regarding port authority performance by governance model. According to them, the infrastructure charges, cargo-handling tariffs, reliability, port preference, contractual flexibility and diversity of services would be better in the public and decentralised governance model than in the private and decentralised governance model. On the other hand, the private and decentralised governance model would be considered as good as the public and decentralised governance model regarding port preference, level of dredging and land accessibility. However, the private and decentralised governance model would be considered better than the public and decentralised governance model regarding operational efficiency. Concerning reliability and port preference, the private and decentralised governance model would be considered better than public and decentralised governance model. For the trade companies, the current public and centralised model performance are under the private and decentralised governance model and the public and decentralised governance model, only aligned with the first one regarding reliability and port preference, but both under the public and decentralised governance model.

Table 2 addresses the port performance perception. According to those main stakeholders, it shows the average perception of port authority performance by governance model. The overall performance perception regarding the current port authorities governance model, that is, public, with centralised port management, with managers named by the Federal Government, is considered a subpar performance expected regardless of the freedom to select port preference by shippers and carriers. On the other hand, according to the respondents, comparatively, with the current model, private and decentralised port management led by private corporations is expected to have good performance, slightly better than the current 


\section{MABR}

7,1

\section{2}

Figure 6.

Exporters competitiveness perception

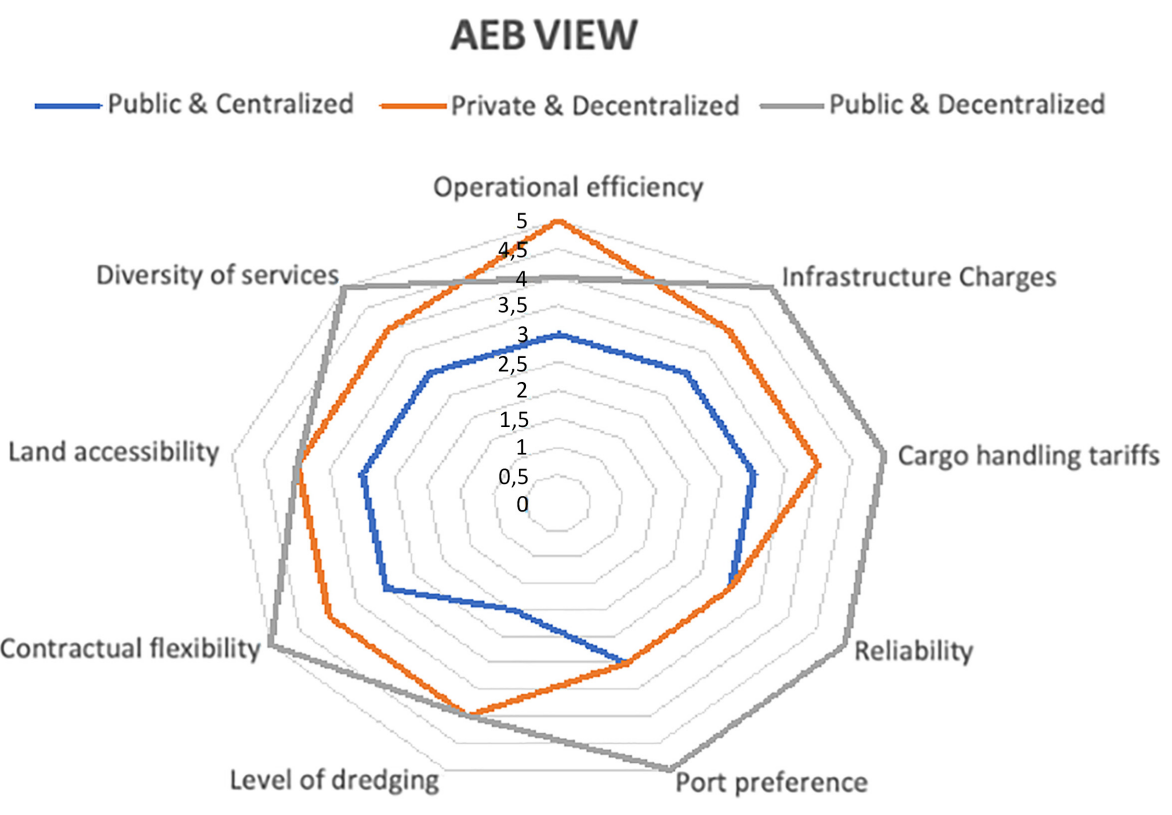

model. However, the private and decentralised model brings a vital concern when key competitiveness points are infrastructure charges, cargo-handling tariffs and reliability in the Port Authority would be worse than they are nowadays. On the other hand, the contractual flexibility to adapt to changes in the market is considered a tremendous positive point in such a governance model.

Finally, comparatively with the current model, according to the respondents, the public and decentralised port management would be expected to have far more overall performance, either by the current model or by the private and decentralised with port management led by a private corporation. The percentage shows the general perception weight regarding the port authority performance, levelled to each governance model. That weight of general perception is calculated by the average of the satisfaction by the port authority governance model, comparatively by the level of perception given by each of the associations. The weight 5 is the most outstanding performance, $100 \%$ satisfaction perception. In Table 2 , a particular assertive highlight as significant performance is the reliability of the public and decentralised Port Authority, which would be considered $100 \%$.

The Brazilian port community represented by the leading associations of the port users, trade companies and port operators show that a fully private model led by private corporations would not bring reliability to the port sector. According to them, public and decentralised port management conducted by managers representing the primary stakeholders would be a better model, bringing reliability fully to the governance system. Table 3 summarises the conclusions about the difficulties that undermine the Brazilian Port Authority's effectiveness and the appropriate countermeasures toward efficiency, flexibility and reliability.

Overall, this research infers that the Belgian model, representing the public port with decentralised governance, with managers named by the PAC, spread an excellent 


\begin{tabular}{lll}
\hline Barriers & Reasons & Countermeasures \\
\hline $\begin{array}{l}\text { Heavy } \\
\text { bureaucracy }\end{array}$ & $\begin{array}{l}\text { Excessive central government control } \\
\text { leads to accountability overload }\end{array}$ & $\begin{array}{l}\text { To enact a new regulatory framework to } \\
\text { facilitate port business based on modern } \\
\text { compliance practices }\end{array}$ \\
$\begin{array}{l}\text { Party-political } \\
\text { influence }\end{array}$ & $\begin{array}{l}\text { The choices by CEOs out of the industry } \\
\text { with party-political focus leads to } \\
\text { inappropriate decisions }\end{array}$ & $\begin{array}{l}\text { CEchoice by the primary stakeholders } \\
\text { includes industries associations, trades, } \\
\text { exporters, importers, shippers, workers, and } \\
\text { local authorities }\end{array}$ \\
$\begin{array}{l}\text { Governance } \\
\text { model }\end{array}$ & $\begin{array}{l}\text { Port legislation demands central } \\
\text { government approval by the port }\end{array}$ & $\begin{array}{l}\text { To enact New National Port Act driving to } \\
\text { the port Authorities decentralisation with } \\
\text { clear restrictions to the party-political } \\
\text { management }\end{array}$
\end{tabular}

Note(s): Drawn by authors based on the findings of this work
Assessment of port governance model

Table 3 .

The main barriers to the port authorities' effectiveness with their appropriate countermeasures

competitive perception for the respondents. However, the private service ports, similar to the Australian model, as private and decentralised port management, led by private corporations, do not transmit a good feeling perception concerning competition issues. Moreover, the UK model does not apply as a comparable situation. The reason is that the traditional concept of Port Authority does not exist in practice in the UK, because of the port privatisation model in force. If a comparison would be made, then it could be said that the UK portsystem is almost like the TPU system in Brazil. Both are responsible for carrying out all the investments, monitoring and operations as presented in Table 1.

\section{Conclusions}

Since 2013, the Brazilian Government has created business environments that were not recommended in the literature for its port authorities, facing its consequences and retrospectively strives to mitigate the problem through regulation, mainly through normative resolutions and ministerial ordinances long-term spiral amendments.

The Government's privatisation agenda implications bring a list of uncertainties regarding the proposed modelling and its attractiveness to private investors. Concerns on the project's financial view, like risk valuation, the rate of return calibration and the freedom to meet the logistics chain with the most significant profitability must be discussed in all projects, supporting classic corporative finance and private governance view. On the other side, concerns about the project's economic outlook must meet the National Master Plan and the local Port Development and Zoning Plan. In addition, they must address the extension of tariff freedom and the expansion projects driven by private or public policies. How to calibrate the scales to meet the needs and correctly balance all factors is a complex equation.

Hence, this research finds that the remedy to overcome the main problems in Brazilian Port Authority governance is in the Federal Government's hands: removing the heavy bureaucracy, preventing the usual party-political influence and decentralising port managing. Thus, a comprehensive port governance improvement based on landlord port model evolution seems to be more engaged to the outstanding port management quality worldwide than a private service port could provide to the Brazilian case.

\section{References}

Australian Competition and Consumer Commission (ACCC) (2020), "Container stevedoring monitoring report 2019-20", available at: https://www.accc.gov.au/publications/container-stevedoringmonitoring-report/container-stevedoring-monitoring-report-2019-20 (accessed 19 August 2021). 
MABR

7,1

84
Baird, A.J. (2000), "Port privatisation: objectives, extent, process, and the UK experience", International Journal of Maritime Economics, Vol. 2 No. 3, pp. 177-194.

Baird, A.J. and Valentine, V.F. (2006), "Port privatisation in the United Kingdom", Research in Transportation Economics, Vol. 17, pp. 55-84.

Barros, C.F.S. and Barros, C.M. (2013), "Suitability of Brazilian ports to international standards of port needs: a case study in the port of Salvador", Journal of Transport Literature, Vol. 4 No. 4, pp. 23-49.

Brooks, M.R. and Pallis, A.A. (2012), Classics in Port Policy and Management, Edward Elgar, Cheltenham.

Chen, P.S.-L., Pateman, H. and Sakalayen, Q. (2017), “The latest trend in Australian port privatisation: drivers, processes and impacts", Research in Transportation Business and Management, Vol. 22, pp. 201-213.

Court of Auditors of the Union (CAU) (2020), "National Audit Office Report comparing organized ports and private use ports | Portal TCU", available at: https:/portal.tcu.gov.br/imprensa/noticias/ auditoria-do-tcu-compara-portos-organizados-a-terminais-de-uso-privado.htm (accessed 19 August 2021).

European Sea Ports Organisation (2010), "European port governance", available at: https://www.espo. be/media/espopublications/espofactfinding report2010.pdf (accessed 18 August 2021).

Galvão, C.B., Robles, L.T. and Guerise, L.C. (2013), "The Brazilian seaport system: a post-1990 institutional and economic review", Research in Transportation Business and Management, Vol. 8, pp. 17-29.

Galvão, C.B., Robles, L.T. and Guerise, L.C. (2017), "20 years of port reform in Brazil: insights into the reform process", Research in Transportation Business and Management, Vol. 22, pp. 153-160.

Lunkes, R.J., Ripoll-Feliu, V., Giner-Fillol, A. and Rosa, F.S. (2013), "Performance-based budgeting study of the implementation in valenciaport", Brazilian Journal of Public Administration (RAP), Vol. 47 No. 1, pp. 49-76.

Maritime UK (2021), “The collective voice for the UK's maritime industries”, available at: https://www. maritimeuk.org (accessed 18 August 2021).

Notteboom, T.E. and Winkelmans, W. (2001), "Structural changes in logistics: how will port authorities face the challenge?”, Maritime Policy and Management, Vol. 28 No. 1, pp. 71-89.

National Waterway Transportation Agency (NWTA) (2021), Statistical Yearbook, available at: http:// web.antaq.gov.br/anuario/ (accessed 18 August 2021).

Notteboom, T.E., Pallis, A. and Rodrigue, J.P. (2021), Port Economics, Management and Policy, Routledge, New York, NY.

Paixão, A.C. and Bernard Marlow, P. (2003), "Fourth generation ports - a question of agility?", International Journal of Physical Distribution and Logistics Management, Vol. 33 No. 4, pp. 355-376.

Peters, H.J.F. (2001), "Developments in global seatrade and container shipping markets: their effects on the port industry and private sector involvement", International Journal of Maritime Economics, Vol. 3 No. 1, pp. 3-26.

Portogente, R. (2020), "Minfra wants more active participation from private initiative in modernising Brazilian ports", available at: https://portogente.com.br/noticias/transporte-logistica/112345minfra-quer-participacao-mais-ativa-da-iniciativa-privada-na-modernizacao-dos-portos-br (accessed 19 August 2021).

Saundry, R. and Turnbull, P. (1997), "Private profit, public loss: the financial and economic performance of UK ports", Maritime Policy and Management, Vol. 24 No. 4, pp. 319-334.

Tongzon, J.L. (1995), "Determinants of port performance and efficiency”, Transportation Research Part A: Policy and Practice, Vol. 29 No. 3, pp. 245-252. 
Tovar, B. and Wall, A. (2014), "The impact of demand uncertainty on port infrastructure costs: useful information for regulators?”, Transport Policy, Vol. 33, pp. 176-183.

Van der Lugt, L.M., de Langen, P.W. and Hagdorn, L. (2017), "Strategic beliefs of port authorities", Transport Reviews, Vol. 37 No. 4, pp. 412-441.

Victorian Transport Association (2020), "Media releases", available at: https://vta.com.au (accessed 19

Assessment of port

governance

model August 2021).

World Bank (2007), The Evolution of Ports in a Competitive World - Port Reform Toolkit Second Edition the World Bank, available at: https:/ppiaf.org/sites/ppiaf.org/files/documents/toolkits/ Portoolkit/Toolkit/pdf/modules/02 _toolkit_Module2.pdf (accessed 10 July 2021).

Zheng, S. and Negenborn, R.R. (2014), "Centralization or decentralization: a comparative analysis of port regulation modes", Transportation Research Part E: Logistics and Transportation Review, Vol. 69, pp. 21-40.

\section{Corresponding author}

Cláudio de Jesus Marques Soares can be contacted at: claudio.soares@portosrio.gov.br

For instructions on how to order reprints of this article, please visit our website:

www.emeraldgrouppublishing.com/licensing/reprints.htm

Or contact us for further details: permissions@emeraldinsight.com 